\title{
Evaluation of Drip Fertigation System under Different Fertigation Levels for Okra Crop
}

\author{
Puneet Sharma $^{1 *}$ and Arun Kaushal ${ }^{2}$ \\ Department of Soil and Water Engineering, Punjab Agricultural University, Ludhiana- \\ 141004, Punjab, India \\ *Corresponding author
}

\section{A B S T R A C T}

\section{Keywords}

Drip fertigation, Emitter discharge, Uniformity Coefficient, Evaluation, Okra

Article Info

Accepted: 07 November 2018 Available Online: 10 December 2018
Drip fertigation is the technique of application of suitable quality of water for irrigation purpose along with fertilizer to provide water and fertilizer efficient condition for growth and development of plants. A study on field evaluation of drip fertigation system for Okra crop was conducted under sandy loam soil conditions of Ludhiana district of Punjab state (India). There were nine treatments consisting of combination of three fertilizer levels $(60 \%, 80 \%$ and $100 \%$ of RDF) and three irrigation levels $(0.6,0.8$ and 1.0 of IW/CPE ratio). Emitter discharge measured at 15 days interval for the entire crop season was used to check the performance of drip fertigation system by evaluating Christiansen Uniformity Coefficient (CUC) and Lower Quartile Distribution Uniformity (LQDU).Emitter discharge, CUC and LQDU varied from $0.81 \mathrm{lph}$ to $1.2 \mathrm{lph}, 92.1 \%$ to $95.6 \%$ and $83.1 \%$ to $88.7 \%$ respectively. It was observed that there was non-significant variation of emitter discharge, CUC and LQDU within the treatments although Emitter discharge, CUC and LQDU decreased with time intervals.

\section{Introduction}

Water is an essential requirement in agricultural production. Water resources in India at present face many challenges, including increasing demands in many sectors it is important to judiciously use the already existing water resources by using suitable irrigation technology that not only increases vegetable production per unit area but also per unit of water used. Thus, a scientific and efficient management of water is needed especially in hot dry months of pre-monsoon period, to enhance water productivity and yield of crop especially vegetables (Bozkurt and Ozekici, 2006; Changade et al., 2009; Kaushal et al., 2012 and Kumari, 2014).

Drip irrigation is the technique in which water is supplied to roots of plants at controlled rate. Application of water-soluble fertilizers in recommended quantities can also be done along with water in drip irrigation which is technically termed as 'Drip Fertigation'. Drip fertigation technology is more suitable to save a substantial amount of water, fertilizers and helps to increase the productivity as reported by several researchers (Zhao et al., 2012, Patel 
and Rajput 2007\&Kumari 2014). Some potential advantages of fertigation are improved efficiency of fertilizer recovery, minimal fertilizer losses due to leaching, control of nutrient concentration in soil solution, flexibility in timing of fertilizer application in relation to crop demand based on development and physiological stage of crops. By minimizing fertilizer and water losses it gives economic benefit to the crop grower (Imtiyaz et al., 2000; Okunade et al., 2009; Woltering et al., 2011; Rajaraman and Pugalendhi, 2013; Darouich et al., 2014 and Kumari and Kaushal, 2015).

Uniformity of drip fertigation system is an important aspect of crop production as indicated by (Bralts et al., 1981 and Arya et al., 2017). Over as well as deficit irrigation conditions may occur due to low uniformity. Various studies on performance of emitters (Bralts et al., 1979 and Chandra and Singh, 2018) indicated that there is decrease in uniformity due to several factors. Drip irrigation is known as the most efficient method of applying irrigation water. Drip fertigation involves use of fertilizers with water. So different fertigation treatments will have different concentrations of fertilizer in the irrigation water solution, which may affect uniformity of drip system and may cause clogging of emitters. So, to evaluate the performance of the drip fertigation system the present study was undertaken.

\section{Materials and Methods}

The field study was done in year 2014 at the Research Farm, Department of Soil and Water Engineering, PAU, Ludhiana, India (Latitude $30^{\circ} 56^{\prime} \mathrm{N}$, Longitude $75^{\circ} 52^{\prime} \mathrm{E}$ and 247 meters above mean sea level). Soil textural classification of the experimental site was sandy loam. The crop grown was Okra (variety: Punjab-8).The nine treatments of the experiment consisted of combination of three irrigation and three fertilizer levels. Fertilizer levels consisted of $\mathrm{F}_{1}(60 \%$ of recommended fertilizer dose $\mathrm{N}$ ), $\mathrm{F}_{2}$ ( $80 \%$ of recommended fertilizer dose $\mathrm{N})$ and $\mathrm{F}_{3} \quad(100 \%$ of recommended fertilizer dose $\mathrm{N}$ ) based on recommended fertilizer dose $(92 \mathrm{kgN}$ per ha) mentioned in 'Package of practices for cultivation of vegetables, PAU, Ludhiana' (Anon. 2013). Irrigation levels consisted of Drip with IW/CPE (irrigation water/ cumulative pan evaporation) ratio $\mathrm{I}_{1}$ (Drip with IW/CPE ratio 0.60), I $\mathrm{I}_{2}$ (Drip with IW/CPE ratio 0.80) and $\mathrm{I}_{3}$ (Drip with IW/CPE ratio 1.00$)$.

The experimental design was split plot design with nine treatments and three replications for each treatment. Pre-sowing irrigation (rauni) with the depth of about $80 \mathrm{~mm}$ was applied. Well rotten farm yard manure @ 50 tonnes per hectare was incorporated in experimental area, 15 days before sowing to enable it to properly mix with the soil. The land area was tilled, planked and then levelled properly. $50 \mathrm{~cm}$ wide beds were prepared with a spacing of 50 $\mathrm{cm}$ in between each bed. In the experiment, the drip system consisted of laterals of $12 \mathrm{~mm}$ diameter having inline emitters with manufacturing discharge of $1.3 \mathrm{lph}$ and emitter size of $0.3 \mathrm{~mm}$.

In each experimental treatment and replication, tumblers were placed below emitters at four locations of each lateral (at first emitter, at $1 / 4^{\text {th }}$ lateral length, at $3 / 4^{\text {th }}$ lateral length and at last emitter) for measuring the discharge of emitter to evaluate the performance of drip fertigation system, which was repeated after every 15days interval.

From observed emitter discharges of every replication and treatment Christiansen Uniformity Coefficient and Lower quartile distribution uniformity were calculated after every 15 days interval during the whole of 
crop season to evaluate the variation in emitter flow rate due to fertigation.

The Christiansen uniformity coefficient give information related to uniformity of water application through drip fertigation system, the values were calculated as per the equation (1.) given below (Bralts and $\mathrm{Wu}, 1979$ and Bralts et al., 1987):

$\mathrm{CUC}=100\left(1-\frac{\Delta \bar{q}}{\bar{q}}\right\}$

Where, $\mathrm{CUC}=$ Christiansen uniformity coefficient $(\%)$

$\Delta^{\bar{q}}=$ Mean absolute deviation of the emitter flow from the mean value (lph)

$\bar{q}=$ Average discharge (lph)

Lower Quartile Distribution Uniformity (LQDU) was calculated as given below by equation (2.) as given below (ASAE, 2003):

$\mathrm{LQDU}=100\left(\mathrm{Q}_{\mathrm{LQ}} / \overline{\bar{q}}\right)$

Where, LQDU = Lower Quartile Distribution Uniformity (\%),

$\mathrm{Q}_{\mathrm{LQ}}=$ The average of lowest 1/4th of the emitter flow rate (lph),

$\bar{q}=$ Average discharge (lph)

The data analyzed from the field experiment was subjected to statistical analysis using split-plot design and using analysis of variance (ANOVA) techniques at 5\% level of significance, by using CPCS1 software.

\section{Results and Discussion}

The results show that decrease in discharge is minimum in $F_{1} I_{1}$ followed by all other treatments as illustrated in figure 1. Among the drip fertigation treatments, discharge decreased from 8 to $11 \%$ and varied from 0.81 lph to $1.2 \mathrm{lph}$. In all the treatments emitter discharge decreased as the experiment progresses but there was non-significant difference between all the treatments. This may be due to the solubility of the Urea fertilizer with water.

The results are in accordance with that of (Samani and Nasab, 2012; Bozkurt and Ozekici, 2006).

Christiansen Uniformity Coefficient (CUC) results are presented in Table 1, as seen from it, CUC has high values as per the typical characteristics of a good drip irrigation system (Keller and Karmeli, 1974; Hills et al., 1989; Mane et al., 2008; Zamaniyan et al., 2013 and Arya et al., 2017) and it is minimum in $\mathrm{F}_{3} \mathrm{I}_{2}$ i.e. $92.1 \%$ and maximum in $\mathrm{F}_{1} \mathrm{I}_{1}$ i.e. $95.6 \%$. In all the treatments CUC decreased with time which is in accordance with Hills et al., (1989) and Arya et al., (2017) but there was nonsignificant difference between all the treatments.

Lower Quartile Distribution Uniformity (LQDU) results are shown in Table 2 and as per good drip system design criteria it is having a high value which ranges from $83.1 \%$ to $88.7 \%$ (Zamaniyan et al., 2013). There was non-significant difference between all the treatments. In all the treatments LQDU decreased with time which is in accordance with Zamaniyan et al., (2013) and Arya et al., (2017) but there was non-significant difference between all the treatments.

From the above study it is concluded that for different fertigation treatments there was nonsignificant variation on Emitter discharge, Christiansen Uniformity Coefficient (CUC) and Lower Quartile Distribution Uniformity (LQDU) and the performance of drip fertigation system was excellent. 
Table.1 Christiansen uniformity coefficient of drip fertigation system for different treatments

\begin{tabular}{|c|c|c|c|c|c|c|c|c|c|c|c|c|}
\hline \multicolumn{13}{|c|}{ Christiansen Uniformity Coefficient (\%) } \\
\hline \multirow[t]{2}{*}{ Treatments } & \multicolumn{12}{|c|}{ Dates } \\
\hline & $\begin{array}{r}\text { 01- } \\
\text { Apr }\end{array}$ & $\begin{array}{r}\text { 16- } \\
\text { Apr }\end{array}$ & $\begin{array}{r}\text { 30- } \\
\text { Apr }\end{array}$ & $\begin{array}{r}\text { 01- } \\
\text { May }\end{array}$ & $\begin{array}{r}\text { 15- } \\
\text { May }\end{array}$ & $\begin{array}{r}\text { 30- } \\
\text { May }\end{array}$ & $\begin{array}{l}\text { 01- } \\
\text { Jun }\end{array}$ & $\begin{array}{l}\text { 16- } \\
\text { Jun }\end{array}$ & $\begin{array}{l}\text { 30- } \\
\text { Jun }\end{array}$ & $\begin{array}{l}\text { 01- } \\
\text { Jul }\end{array}$ & $\begin{array}{l}\text { 16- } \\
\text { Jul }\end{array}$ & 30-Jul \\
\hline F1I1 & 95.2 & 95.6 & 94.7 & 94.7 & 94.5 & 93.5 & 94.2 & 94.8 & 93.7 & 94.7 & 93.9 & 93.8 \\
\hline F1I2 & 95.1 & 94.3 & 94.6 & 94.5 & 94.5 & 94.9 & 93.9 & 94.8 & 94.9 & 93.5 & 93.6 & 93.5 \\
\hline F1I3 & 94.5 & 93.7 & 95.3 & 94.6 & 94.8 & 94.8 & 94.7 & 93.4 & 93.8 & 94.0 & 93.7 & 93.3 \\
\hline F2I1 & 93.2 & 93.4 & 94.3 & 94.4 & 93.9 & 95.1 & 95.0 & 94.9 & 94.7 & 93.9 & 93.6 & 92.9 \\
\hline F2I2 & 94.4 & 94.5 & 95.5 & 93.7 & 93.8 & 93.4 & 95.1 & 94.4 & 94.6 & 93.4 & 93.9 & 93.6 \\
\hline F2I3 & 94.3 & 94.2 & 93.9 & 93.9 & 94.7 & 93.9 & 94.5 & 94.7 & 94.8 & 94.8 & 94.7 & 93.5 \\
\hline F3I1 & 93.1 & 92.4 & 94.7 & 93.7 & 94.1 & 94.7 & 93.7 & 93.9 & 93.4 & 94.7 & 92.8 & 93.1 \\
\hline F3I2 & 93.4 & 94.4 & 94.8 & 94.8 & 93.8 & 92.1 & 94.7 & 95.0 & 93.5 & 95.2 & 93.8 & 93.7 \\
\hline F3I3 & 94.6 & 94.5 & 95.2 & 94.2 & 94.2 & 93.7 & 94.1 & 92.8 & 94.8 & 93.8 & 93.9 & 93.9 \\
\hline CD (5\%) & NS & NS & NS & NS & NS & NS & NS & NS & NS & NS & NS & NS \\
\hline
\end{tabular}

Table.2 Lower quartile distribution uniformity of drip fertigation system for different treatments

\begin{tabular}{|c|c|c|c|c|c|c|c|c|c|c|c|c|}
\hline \multicolumn{13}{|c|}{ Lower Quartile Distribution Uniformity (\%) } \\
\hline \multirow[t]{2}{*}{ Treatments } & \multicolumn{12}{|c|}{ Dates } \\
\hline & $\begin{array}{l}\text { 01- } \\
\text { Apr }\end{array}$ & $\begin{array}{l}\text { 16- } \\
\text { Apr }\end{array}$ & $\begin{array}{l}\text { 30- } \\
\text { Apr }\end{array}$ & $\begin{array}{l}\text { 01- } \\
\text { May }\end{array}$ & $\begin{array}{l}\text { 15- } \\
\text { May }\end{array}$ & $\begin{array}{c}\text { 30- } \\
\text { May }\end{array}$ & $\begin{array}{l}\text { 01- } \\
\text { Jun }\end{array}$ & $\begin{array}{l}\text { 16- } \\
\text { Jun }\end{array}$ & $\begin{array}{l}\text { 30- } \\
\text { Jun }\end{array}$ & $\begin{array}{l}\text { 01- } \\
\text { Jul }\end{array}$ & $\begin{array}{l}\text { 16- } \\
\text { Jul }\end{array}$ & $\begin{array}{l}\text { 30- } \\
\text { Jul }\end{array}$ \\
\hline F1I1 & 88 & 88.3 & 87.5 & 86.1 & 86.2 & 84.8 & 84.3 & 87.2 & 86 & 84.9 & 84.5 & 84.6 \\
\hline F1I2 & 88.4 & 88.7 & 86.4 & 86.9 & 85.6 & 88.5 & 84.8 & 86.7 & 86.1 & 86.2 & 85.9 & 83.9 \\
\hline F1I3 & 86.6 & 87.3 & 86.4 & 87.4 & 84.3 & 85.6 & 86.5 & 88.2 & 87.2 & 86.1 & 85.1 & 84.6 \\
\hline F2I1 & 87.1 & 86.2 & 87.4 & 87.2 & 86.1 & 84.9 & 83.5 & 87.2 & 86.1 & 85.2 & 84.1 & 84.2 \\
\hline F2I2 & 86.1 & 88.1 & 87.5 & 88 & 85.1 & 87.5 & 84.8 & 85.8 & 88.2 & 85.4 & 84.9 & 84.2 \\
\hline F2I3 & 87.8 & 88 & 87.1 & 87.5 & 88.2 & 84.4 & 86.7 & 86.7 & 87.2 & 85.5 & 83.7 & 84.7 \\
\hline F3I1 & 87.9 & 87.4 & 86.4 & 88.1 & 87 & 84.3 & 85.7 & 85.8 & 85.2 & 86.3 & 84.2 & 83.1 \\
\hline F3I2 & 88.3 & 87.7 & 87.3 & 87.3 & 86.5 & 84.6 & 83.5 & 86.3 & 86.3 & 86.2 & 84.5 & 83.6 \\
\hline F3I3 & 87.9 & 88.5 & 86.3 & 86.3 & 87.1 & 83.8 & 83.5 & 85.9 & 85.1 & 83.2 & 83.1 & 83.4 \\
\hline CD (5\%) & NS & NS & NS & NS & NS & NS & NS & NS & NS & NS & NS & NS \\
\hline
\end{tabular}


Figure.1 Emitter discharge of drip fertigation system for different treatments

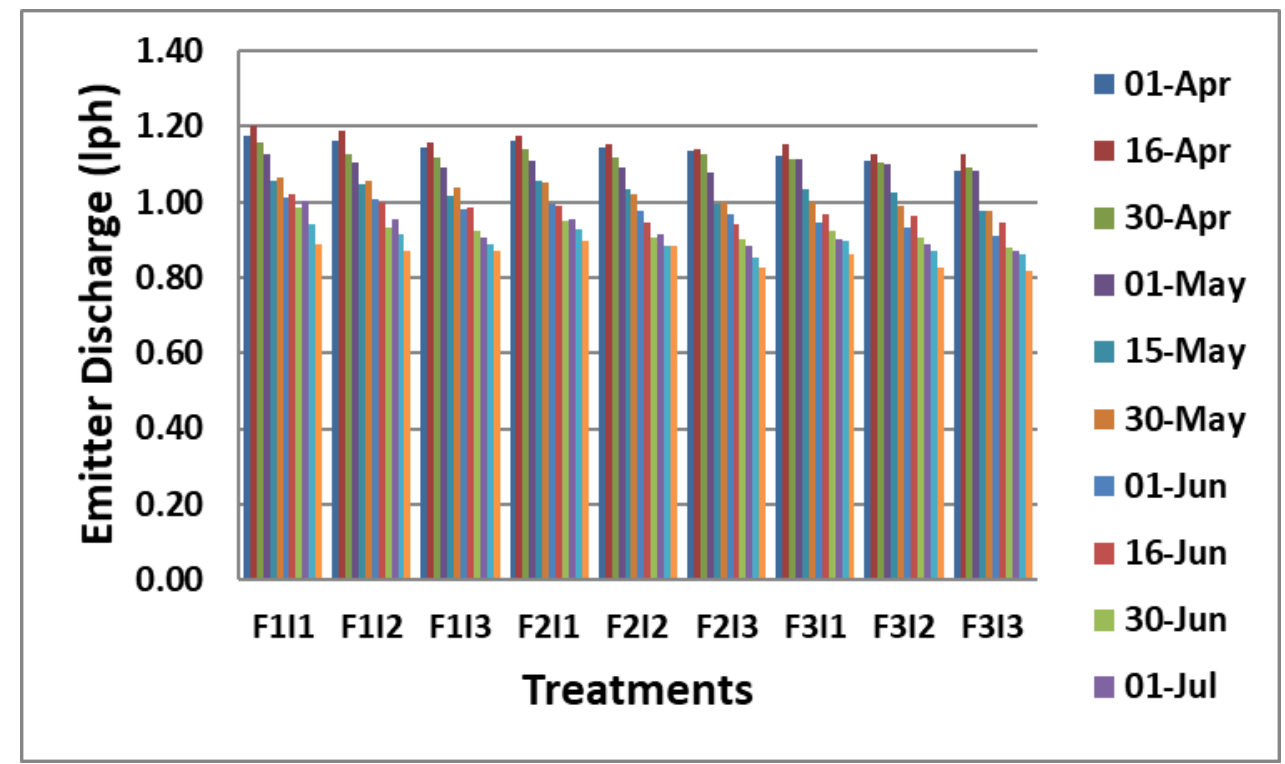

\section{References}

Anonymous. 2013. Package of practices for cultivation of vegetables. Punjab Agricultural University, Ludhiana. Pp 38

Arya, C.K., R.C. Purohit, L.K. Dashora, P.K. Singh and Mahesh Kothari. 2017. Performance Evaluation of Drip Irrigation Systems. Int.J.Curr. Microbiol.App.Sci. 6(4): 2287-2292

ASAE. 2003. Field evaluation of micro irrigation systems. EP458: 760-765.

Bozkurt, S. and Ozekici, B. 2006. The effects of fertigation management on clogging of In-line emitters. J App Sci 6:30343036.

Bralts, V. F. and Wu, I. P. 1979. Emitter flow variation and uniformity for drip irrigation. ASAE Paper No. 79-2099. ASAE, St. Joseph, Mi 49085.

Bralts, V. F., Wu, I. P. and Gitlin, H. 1981. Drip Irrigation Uniformity Considering Emitter Plugging. TRANSACTIONS of the ASAE.

Chandra, R. and Singh, P.K. 2018. Evaluation of Drip Irrigation System for Okra Crop under Tarai Condition of Uttarakhand, India. Int.J.Curr.Microbiol.App.Sci. 7(03): 132-139.

Changade, N.M., Chavan, M.C., Jadhav, S.B. and Bhagyawant, R.G. 2009. Determination of emission uniformity of emitter in gravity fed drip irrigation System. Int. J. Agri. Engi., 2(1): 88-91.

Darouich, H. M., Pedras, C. M. G., Goncalves, J. M. and Periera, L. S. 2014. Drip vs. surface irrigation: a comparison focussing on water saving and economic returns using multicriteria analysis applied to cotton. Bio Sys Engg., 122: 74-90.

Hills, D. J., Nawar, M. N., and Waller, P. M. 1989. Effects of chemical clogging on drip-tape irrigation uniformity. ASAE. 32(4): 1202-1206.

Imtiyaz, M., Mgadla, N. P., Chepete, B. and Manase, S. K. 2000. Response of six vegetable crops to irrigation schedules. Agric Water Manage, 45:331-42.

Kaushal, A., Patole, R. and Singh, K. G. 2012. Drip irrigation in sugarcane : A review. Agri Rev., 33: 211-19.

Keller, J. and Karmeli, D. 1974. Trickle 
irrigation design parameters. Transactions of the American Society of Agri. Engi., 17(4): 678-684.

Kumari, R. 2014. Comparative effects of water soluble and conventional fertilizers on yield and water use efficiency of drip irrigated sweet pepper (Capsicum annuum L. var. grossum). MTech Thesis. Punjab Agricultural University, Ludhiana, India.

Kumari, R. and Kaushal, A. 2015. Economic viability of drip irrigated sweet pepper under different kinds of fertilizers. Env Eco., 33:1322-1326.

Mane, M., Ayare, B. and Magar, S. 2008. Principle of drip irrigation system. Jain Brothers, Maharashtra, India. Pp 3738.

Okunade, D. A., Olanusi, O. A. and Adekalu, K. O.2009. Yield, and economics of okra and amaranth production under irrigation. Int J Veg Sci 15:28-43.

Patel, N. and Rajput, T.B.S. 2007. Effect of drip tape placement depth and irrigation level on yield of potato. Agri. Water Manage., 8: 209-223.

Rajaraman, G. and Pugalendhi, L.2013.Potential impact of spacing and fertilizer levels on the flowering, productivity and economic viability of hybrid Bhendi (Abelmoschus esculentus L. Moench) under drip fertigation system. Amer J Pl Sci., 1:48-54.

Rekha, K. B., Reddy, M. G. and Mahavishnan, K. 2005. Nitrogen and water use efficiency of bhendi (Abelmoschus esculentus L. Moench) as influenced by drip fertigation. $J$ Tropical Agri., 43: 43-46.

Samani, F. A. and Nasab, S. B. 2012. Effect of fertigation on clogging of three types of emitters in Iran. Nat Sci., 10:21-25.

Woltering, L., Ibrahim, A., Pasternak, D. and Ndjeunga, J.2011. The economics of low pressure drip irrigation and hand watering for vegetable production in the Sahel. Agric Water Manage, 99:67-73.

Zamaniyan, M., Fatahi, R., BoroomandNasab, S., Shamohammadi, S. and Parvanak, K. 2013. Evaluation of emitters and water quality in trickle irrigation systems under Iranian conditions. Intl J Agri Crop Sci., 5(15): 1632-1637.

Zhao, W., Li, J., Li, Y. and Yin, J. 2012. Effects of drip system uniformity on yield and quality of Chinese cabbage heads. Agricultural Water Management 110:118-128.

\section{How to cite this article:}

Puneet Sharma and Arun Kaushal. 2018. Evaluation of Drip Fertigation System under Different Fertigation Levels for Okra Crop. Int.J.Curr.Microbiol.App.Sci. 7(12): 588-593.

doi: https://doi.org/10.20546/ijcmas.2018.712.073 